\title{
Waldemar Jaskulski
}

Lubraniec

\section{Podpułkownik Ludwik Kiok (1892-?). Przyczynek do biografii}

Ostatnim - można by rzec - wojennym dowódcą stacjonującego w Suwałkach 4 Dywizjonu Artylerii Konnej był ppłk Ludwik Kiok. Nim ten ambitny artylerzysta objął dowództwo liniowego oddziału wiele lat przesłużył jako wykładowca m.in. w toruńskiej Szkole Strzeleckiej Artylerii. Nieco wcześniej, bo w 1922 r. w jej murach ukończył kurs dowódców dywizjonów.

Ludwik Kiok urodził się 8 lipca 1892 r. ${ }^{1}$ jako poddany cesarza Rosji i króla Polski Aleksandra III. W 1909 r. rozpoczął naukę w Połtawskiej Szkole Mierniczej, którą ukończył 31 lipca 1914 r. Wraz z nim uczyli się tam późniejsi oficerowie Wojska Polskiego, m.in. dowódca II Dywizjonu 16 Pułku Artylerii Polowej, mjr Hektor Żyliński oraz adiutant pułku, kpt. Jan Aleksander Wyspiań$\mathrm{ski}^{2}$. Na początku sierpnia kontynuował naukę w Oficerskiej Szkole Artylerii w Odessie. Ukończył ją w połowie maja 1915 r., awansując do stopnia chorążego. Do 6 sierpnia 1915 r. dowodził plutonem w 2 Lekkiej Samodzielnej Baterii Artylerii. Następnie, w stopniu podporucznika, dowodził plutonem w 110 Brygadzie Artylerii. W marcu 1916 r. awansował na porucznika. Od listopada 1916 r. do stycznia 1917 r. służył w Oddziale Partyzańskim, a następnie dowodził plutonem w 43 Dywizjonie Artylerii. W marcu tego roku wstąpił w szeregi 2 Brygady Artylerii I Korpusu Polskiego ${ }^{3}$. Jest wysoce prawdopodobne, że awans na podkapitana otrzymał już w tej brygadzie. Jednocześnie pełnił funkcję prezesa Wojska

1 W dokumentach podano także datę 21 VII, co wynika z różnicy kalendarza.

2 Wiarygodność tych informacji potwierdził szef Artylerii OK nr I Warszawa gen. bryg. Wincenty Kaczyński.

3 Szerzej H. Bagiński, Wojsko Polskie na Wschodzie 1914-1920, Warszawa 1921, s. 145 i n.; J. Engelgard, Jesień Dowborczyków - udziat kadry I Korpusu Polskiego w tworzeniu Wojska Polskiego i rozbrojeniu Niemców w 1918 roku, „Niepodległość i Pamięć” 2008, nr 28, s. 75 i n.; W. L. Ząbek, Legia Rycerska - prawdy i fikcje. Z dziejów I korpusu Polskiego (1917-1918), „Niepodległość i Pamięć” 2008, nr 28, s. 53 i n.; M. Wrzosek, Polskie korpusy wojskowe w Rosji w latach 1917-1918, Warszawa 1969, s. 72 i n.; J. Dowbór-Muśnicki, Wspomnienia, Warszawa 2003, s. 140. 
Polskiego w 12 Armii. Od sierpnia do końca października 1918 r. pracował w Polskiej Organizacji Wojskowej w Warszawie i Łomży4.

W 1919 r. por. Kiok otrzymał przydział do Instytutu Wojskowo-Geograficznego. Pod koniec tego roku rozkazem ministra spraw wojskowych z 19 listopada został przeniesiony do Generalnego Inspektoratu Artylerii ${ }^{5}$. Wydaje się, że w 1920 r. porucznik otrzymał przydział do Baterii Zapasowej 1 Pułku Artylerii Polowej Legionów rozlokowanej w Warszawie w Cytadeli, a następnie przeniesionej na ul. Koszykową ${ }^{6}$.

Wiosną 1920 r. dowódca 10 Baterii IV Motorowego Dywizjonu 1 Pułku Artylerii Polowej Legionów por. Kiok wyjechał z Warszawy na Ukrainę ${ }^{7}$ W początkowej fazie operacji kijowskiej jego bateria weszła w skład sił głównych I Brygady Piechoty Legionów ppłk Stefana Dęba-Biernackiego. Atak rozpoczęto rankiem 25 kwietnia. „Packardy” wiozące piechotę, w marszu na Wilsk, podobnie jak bateria, ugrzęzły wtedy w piaszczystym terenie ${ }^{8}$. Po tym niepowodzeniu ${ }^{9}$ por. Kioka podporządkowano dowództwu I Dywizjonu 1 Pułku Artylerii Ciężkiej Legionów operującego w Grupie Artylerii ${ }^{10}$ Ciężkiej płk Antoniego Aleksandrowicza.

Za działania na Ukrainie został odznaczony Srebrnym Krzyżem Orderu Wojskowego Virtuti Militari nr 271711. [...] Na wojnie 1919/20 - wspominał Jerzy Kirchmayer - brał udziat $w$ wyprawie kijowskiej $w$ składzie grupy artylerii cięzkiej $w$ armii Śmigłego. Miał dywizjon lub baterię zmotoryzowana. W czasie odwrotu z Kijowa uległ panice, czy też nie przeciwdziałał jej i dopuścit, że zrzucono

4 Centralne Archiwum Wojskowe (dalej CAW), Akta Personalne Kioka Ludwika (dalej AP. Kioka L.), 22551, 10851, Karta ewidencyjna. Zgodność potwierdził dowódca 10 Pułku Piechoty płk dypl. Stefan Kossecki.

5 Dz. Rozkazów Wojskowych nr 97 z 27 XII 1919 r., s. 2674.

6 W. Chocianowicz, Dzieje 1 Pułku Artylerii Lekkiej Legionów Józefa Pitsudskiego, Londyn 1967, s. 265-266, 427; M. Wrzosek, Wojny o granice Polski Odrodzonej 1918-1921, Warszawa 1992, s. 110; J. Odziemkowski, Piechota polska $w$ wojnie z Rosja bolszewickq 1919-1920, Warszawa 2010, s. 362.

7 M. Wiśniewski, Zarys historii wojennej 16-go Pułku Artylerii Polowej, Warszawa 1929, s. 7.

8 A. J. Borkiewicz, Dzieje 1-go Pułku Piechoty Legionów. (Lata wojny polsko-rosyjskiej 1918-1920), Warszawa 1929, s. 488, 492.

9 Po zajęciu Wilska samochody zostały oddane do dyspozycji dowódcy III Brygady Piechoty Legionów ppłk Jozefa Olszyny-Wilczyńskiego, którego pułki maszerowały traktem.

10 Pieczęć z tą nazwą figuruje na wniosku na odznaczenie orderem Virtuti Militari V kl. z $30 \mathrm{~V}$ 1920 r. Nazywana także Grupą Ciężkiej Artylerii; vide S. J. Tym, Organizacyjne podstawy operacji zaczepnej Wojska Polskiego na Ukrainie wiosna 1920 roku, [w:] Wojna polsko-rosyjska 1919-1920 i jej międzynarodowe odniesienia z perspektywy 90-lecia, red. nauk. J. Ślipiec, T. Kośmider, Warszawa 2010, s. 106.

11 CAW, AP. Kioka L., 22551, 10851, Wniosek na odznaczenie orderem Virtuti Militari V k1. z 30 V 1920 r.; G. Łukomski, B. Polak, A. Suchcitz, Kawalerowie Virtuti Militari 1792-1945. Wykazy odznaczonych za czyny z lat 1863-1864, 1914-1945, Koszalin 1993, s. 187. 
drogocenny sprzęt $z$ wysokiego nasypu szosy $w$ dót (może byto to $w$ rzeczywistości nieco inaczej, ale tak to sobie opowiadano w pułku). Wnet jednak wyjaśniło się, ze alarm byt fatszywy i strata niepotrzebna. $[\ldots]^{12}$. W czasie odwrotu por. Kiok dowodził nadal 10 Baterią, a po jej rozformowaniu 7 Baterią w III Dywizjonie 1 Pułku Artylerii Polowej Legionów. Na jej czele, w szeregach 1 Dywizji Piechoty Legionów bił się m.in. 28 września pod Lidą ${ }^{13}$.

30 sierpnia 1920 r. dowódca III Dywizjonu mjr Aleksander Hertel ${ }^{14}$ wystąpił z wnioskiem o nadanie mu Srebrnego Krzyża Orderu Wojskowego Virtuti Militari. Wniosek poparli kolejni przełożeni: dowódca pułku ppłk Kazimierz Schally ${ }^{15}$, dowódca 1 Brygady Artylerii Legionów ppłk Witold Julian Światopełk-Mirski, dowódca 1 Dywizji Piechoty Legionów płk Stefan Dąb-Biernacki oraz dowódca frontu gen. por. Edward Rydz-Śmigły ${ }^{16}$. Jako kawaler Orderu Wojskowego Virtuti Militari por. Kiok figuruje w szeregach 1 Pułku Artylerii Polowej Legionów. Ponadto jako jednemu z szesnastu żołnierzy tego pułku nadano mu czterokrotnie Krzyż Walecznych ${ }^{17}$.

Jeszcze w czasie działań zbrojnych dekretem Wodza Naczelnego L. 2355 z 14 października 1920 r. kpt. Kiok z 16 Pułku Artylerii Polowej został zatwierdzony w posiadanym stopniu ze starszeństwem z 1 kwietnia 1920 r. ${ }^{18}$

Po wojnie pozostał w legionowym pułku. Od 8 sierpnia do 20 października 1921 r. uczestniczył w kursie dowódców batalionów przeprowadzonym w Głównym Centrum Wyszkolenia w Rembertowie. Kierownik centrum, płk Władysław Dragat potwierdził, że kapitan kurs ten ukończył z oceną bardzo dobrą, zajmując 1 lokatę na 67 słuchaczy. Ponadto za dowodzenie baterią, jesienią $1921 \mathrm{r}$. dowódca dywizjonu mjr Władysław Filipkowski ${ }^{19}$ wystawił kpt. Kiokowi ocenę bardzo dobrą. 10 listopada notę tę potwierdził dowódca pułku ppłk Schally, a wkrótce dowódca dywizji płk. Dąb-Biernacki²0.

Prawdopodobnie na początku października 1921 r. otrzymał dowództwo stacjonującego w Grodnie I Dywizjonu formującego się 3 Pułku Artylerii Ciężkiej. Wiosną 1922 r. dywizjon został przeniesiony do Wilna, gdzie mieściło się do-

\footnotetext{
12 J. Kirchmayer, Pamiętniki, Warszawa 1962, s. 199.

13 R. Lewicki, Zarys historii wojennej 1-go Pułku Artylerii Polowej Legionów, Warszawa 1929, s. 48.

14 Dz. Rozkazów Wojskowych nr 91 z 2 X 1919 r., s. 2227-2228. Na tym stanowisku został zatwierdzony rozkazem MSWojsk. z 26 VIII 1919 r.; W. K. Cygan, Oficerowie Legionów Polskich 1914-1917. Słownik biograficzny, t. II, Warszawa 2006, s. 113.

15 W. K. Cygan, Oficerowie Legionów..., t. IV, Warszawa 2006, s. 204.

16 CAW, AP. Kioka L., 22551, 10851, Wniosek na odznaczenie orderem Virtuti Militari V k1.

17 R. Lewicki, op. cit., s. 56.

18 Dz. Personalny MSWojsk., Nr 40 z 20 X 1920 r., s. 1068.

19 Ibidem, s. 285.

20 CAW, AP. Kioka L., 22551, 10851, Roczne uzupełnienie listy kwalifikacyjnej za rok 1921.
} 
wództwo pułku z pełniącym obowiązki dowódcy tytularnym płk Eugeniuszem Habichem $^{21}$. W tym pułku zastał Kioka koniec pracy Komisji Weryfikacyjnej. Dekretem L. 19400/O. V z 3 maja 1922 r. Naczelnik Państwa zatwierdził mu stopień majora ze starszeństwem z 1 czerwca 1919 r., lokata $149^{22}$.

Po włączeniu do pułku dwóch baterii przybyłych z Grudziądza (IV 1922) korpus oficerski przedstawił Jerzy Kirchmayer:

- pełniący obowiązki dowódcy pułku tyt. płk Eugeniusz Habich;

- zastępca - w zastępstwie mjr Włodzimierz Arvaniti²3;

- kwatermistrz - mjr Franciszek Fielek;

- komendant szkoły podoficerskiej - kpt. Franciszek Mołodyński;

- adiutant pułku - por. Jan Orłowski;

- oficer zwiadowczy - ppor. Jerzy Kamiński;

- oficer łączności - por. Marian Perzyński;

- oficer finansowy - kpt. Adam Hauer;

- oficer prowiantowy - por. Jan Pacyk;

- oficer ewidencji personalnej - por. Michał Skiba;

- oficer kwaterunkowy - por. Henryk Bełdycki;

- lekarz weterynarii - mjr Jakub Landfisz;

- młodszy lekarz - kpt. lek. Jerzy Dobrzański;

I Dywizjon (w Grodnie) - mjr Ludwik Kiok;

1 Bateria - kpt. Witold Gostyński;

2 Bateria - kpt. Gustaw Piwakowski;

3 Bateria - kpt. Hieronim Suszczyński.

Ponadto w I Dywizjonie służyli: ppor. Janusz Araszkiewicz, por. Feliks Cydzik, por. Alfred Prager, por. Adam Bolesław Kropiński, por. Janusz Zaleszczyński.

II Dywizjon - mjr Włodzimierz Lewgowd;

4 Bateria - kpt. Jan Bigocki;

5 Bateria - kpt. Władysław Garlicki;

6 Bateria - kpt. Antoni Wojtanowicz;

III Dywizjon - kpt. Witold Kamiński (6 VI 1888);

7 Bateria - kpt. Bohdan Komalski;

8 Bateria - w zastępstwie ppor. Paweł Klingenberg, następnie por. Witold Zapaśnik;

9 Bateria - kpt. Kazimierz Michler ${ }^{24}$.

Służący wówczas w 4 Baterii ppor. Jerzy Kirchmayer, po latach tak scharakteryzował, ten okres służby mjr Kioka: Najmniej ciekawy spośród wszystkich oficerów

21 P. Zarzycki, 3 Pułk Artylerii Ciężkiej im. Króla Stefana Batorego, Pruszków 1993, s. 7, 18. Tu podano Habicha jako dowódcę.

22 Lista starszeństwa oficerów zawodowych, Warszawa 1922, s. 191.

23 Zapisywany także jako Arwaniti.

24 J. Kirchmayer, op. cit., s. 170-171. Autor wykazał Habicha jako dowódcę pułku. 
sztabowych pułku był dowódca I dywizjonu, mjr Kiok. Elegancki, bardzo opanowany, niezmiennie grzeczny, często nawet słodki, miał jakaśs niewyraźna przeszłość i przyszłość. [...] W naszym pułku służył krótko. W roku 1922 poszedt na kurs dowódców dywizjonów do Torunia i zostat tam potem jako instruktor. [...] ${ }^{25}$.

Od 20 czerwca do 1 listopada 1922 r. mjr Kiok przebywał na kursie dowódców dywizjonów w Szkole Strzeleckiej Artylerii wchodzącej wówczas w skład Obozu Szkół Artyleriii ${ }^{26}$. Komendant szkoły płk Gustaw Ladziński tak go ocenił: „[...] bardzo dobry oficer, posiada wielki zasób wiadomości fachowych. Zdradzał wielkie zainteresowanie się. Bardzo pilny i pracowity. Taktowny. Nadaje się na dcę dyonu, zcę dcy pułku i instruktora" ${ }^{27}$.

Płk Habich 2 grudnia 1922 r. ocenił go jako bardzo dobrego oficera. Szef Artylerii i Służby Uzbrojenia DOK nr III Grodno gen. bryg. Wincenty Kaczyński pod datą 21 grudnia napisał: „Zgadzam się z oceną i opisem dowódcy pułku”. Natomiast w opinii fachowej generał ten napisał: „Ukończył kurs dców dyonów w Toruniu w roku bieżącym i został wyznaczony do tejże szkoły na instruktora" ${ }^{28}$.

W aktach personalnych Kioka podano, że na stanowisko instruktora w tej szkole odkomenderowany został 23 grudnia 1922 r. na mocy pisma szefa Departamentu III MSWojsk. 7489/2229. Natomiast rozporządzeniem ministra spraw wojskowych, w kwietniu 1923 r. został przydzielony do tej szkoły na stanowisko instruktora grupy dowódców dywizjonów ${ }^{30}$.

Wkrótce powierzono mu kierownictwo kursu dowódców dywizjonów. Z zadania tego wywiązał się bardzo dobrze, co w połowie listopada potwierdził gen. Kaczyński: Jako kierownik kursu dców dyonów okazat się bardzo wymagajacym, co w początku nieco przygniotto stuchaczy, ale za to w późniejszym czasie jego klasa osiagnęła wyniki najlepsze. Przy wykładach i repetycjach dość cięty. Wyktada 1 rok - po nabyciu doświadczeniu i praktyki będzie bez zarzutu ${ }^{31}$.

W połowie października 1923 r. jego bezpośredni przełożony, komendant szkoły płk Ładziński wystawił mu bardzo dobra notę. Drugi w hierarchii przełożony mjr Kioka, komendant Obozu Szkolnego Artylerii gen. Kaczyński opinio-

25 Ibidem, s. 199. Autor scharakteryzował większość oficerów tego pułku począwszy od jego dowódców, a skończywszy na oficerach młodszych.

26 CAW, Centrum Wyszkolenia Artylerii (dalej CWA), I. 340.41.25, Obóz Szkół Artylerii Rozkaz Nr 56 z 9 V 1922 r.

27 CAW, AP. Kioka L., 22551, 10851, Pismo Szkoły Strzeleckiej Artylerii w Toruniu z 6 X 1922 r.; ibidem, Roczne uzupełnienie listy kwalifikacyjnej za rok 1923. W aktach personalnych Kioka podano, że na kursie tym był w okresie 26 VI - 18 XI 1922 r.

28 CAW, AP. Kioka L., 22551, 10851, Roczne uzupełnienie listy kwalifikacyjnej za rok 1922.

${ }^{29}$ CAW, AP. Kioka L., 22551, 10851, Karta ewidencyjna. Niewykluczone, że funkcję tę sprawował wcześniej.

30 Dz. Personalny MSWojsk., Nr 19 z 30 III 1923 r., s. 224; CAW, CWA, I. 340.41.25, Obóz Szkolny Artylerii Rozkaz Nr 30 z 4 IV 1923 r.

31 CAW, AP. Kioka L., 22551, 10851, Roczne uzupełnienie listy kwalifikacyjnej za rok 1923. 
wał go 15 listopada. Jako instruktora kursów dowódców dywizjonów ocenił go następująco:

I. Zalety osobiste: wybitnie prawy, szczery, obowiązkowy;

II. Zdolności fizyczne: wybitne;

III. Inteligencja: wybitna;

IV. Zdolności kierownicze: wybitne, bardzo wymagający;

V. Zdolności organizacyjne: bardzo dobre;

VI. Zdolności wychowawcze: wybitne;

VII. Wartość służby: bardzo duża;

VIII. Ogólna ocena: wybitny.

Ponadto generał ten zaproponował jego kandydaturę na stanowisko komendanta szkoły artylerii lub zastępcę dowódcy pułku ${ }^{32}$. Następca płk Ładzińskiego, pełniący obowiązki komendanta szkoły płk Wiktor Aleksandrowicz 20 października 1924 r. podniósł ocenę ogólną do wybitnej. Identyczną notę wystawił 5 listopada gen. Kaczyński. Ponadto w opinii fachowej komendant obozu zanotował: „Wybitny teoretyk i praktyk art. i wybitny instruktor"33.

Pomimo uzyskania bardzo dobrych not propozycje przeniesienia go do linii nie znalazły posłuchu u przełożonych. Wszak przeniesienie do stolicy należy uznać za awans. Pod koniec października 1924 r. rozporządzeniem ministra spraw wojskowych został przydzielony ze Szkoły Strzeleckiej Artylerii do Doświadczalnego Centrum Wyszkolenia na stanowisko wykładowcy ${ }^{34}$. W listopadzie $1925 \mathrm{r}$. został przeniesiony ewidencyjnie z tego pułku do Kadry Oficerów Korpusu Artylerii przy Departamencie III MSWojsk. z pozostawieniem na dotychczas zajmowanym stanowisku ${ }^{35}$.

I na tym stanowisku major dał się poznać z jak najlepszej strony. Dyrektor nauk mjr SG Mieczysław Czaderski 29 października 1925 r. wystawił mu najwyższą notę. Generalny Inspektor Artylerii gen. broni Józef Haller następnego dnia zapisał: „Zgadzam się z oceną Dyrektora Nauk. [...] Na obecnym stanowisku odpowiada bardzo dobrze. Nadaje się na zcę dcy pułku. [...] Wybitny oficer sztabowy" ${ }^{36}$.

Wydaje się, że dopiero te opinie przyczyniły się do powierzenia mu stanowiska liniowego. Rozporządzeniem ministra spraw wojskowych został przeniesiony z dniem 18 kwietnia 1926 r. na stanowisko dowódcy 8 Dywizjonu Artylerii Konnej ${ }^{37}$. Przeniesienie na to stanowisko znacznie zwiększało możliwo-

32 CAW, AP. Kioka L., 22551, 10851, Roczne uzupełnienie listy kwalifikacyjnej za rok 1923.

33 CAW, AP. Kioka L., 22551, 10851, Roczne uzupełnienie listy kwalifikacyjnej za rok 1924.

34 Rocznik oficerski 1923, Warszawa 1923, s. 783, 816; Rocznik oficerski 1924, Warszawa 1924, s. 702,739 .

35 Dz. Personalny MSWojsk., Nr 119 z 12 XI 1925 r., s. 640 - 641.

36 CAW, AP. Kioka L., 22551, 10851, Roczne uzupełnienie listy kwalifikacyjnej za rok 1925.

37 Dz. Personalny MSWojsk., Nr 15 z 27 III 1926 r., s. 102. 
ści awansu. Droga do stanowiska szefa artylerii korpusu, a następnie dowódcy grupy artylerii choć daleka, stała otworem. W dalszej perspektywie mógł zostać dowódcą piechoty dywizyjnej, nie wykluczając możliwości objęcia dowództwa dywizji piechoty ${ }^{38}$.

Obowiązki objął 16 maja 1926 r. ${ }^{39}$, a więc po zamachu majowym. Zastąpił na tym stanowisku ppłk Adama Sielickiego, którego przeniesiono na zastępcę dowódcy 22 Pułku Artylerii Polowej ${ }^{40}$. Miejscem służby majora stał się Białystok. W tym garnizonie miał swoją siedzibę wraz ze sztabem dowódca 1 Dywizji Kawalerii gen. bryg. Juliusz Rómmel, zastąpiony jesienią 1926 r. przez płk Stefana Grabowskiego. W skład tej wielkiej jednostki kawalerii wchodziły:

- IV Brygada Kawalerii (Suwałki) - 3 Pułk Szwoleżerów i 2 Pułk Ułanów;

- VIII Brygada Kawalerii (Wołkowysk a następnie Baranowicze) - 10 Pułk Ułanów i 3 Pułk Strzelców Konnych;

- XI Brygada Kawalerii (Augustów) - 1 Pułk Ułanów i 9 Pułk Strzelców Konnych;

- 4 Dywizjon Artylerii Konnej, 1 Szwadron Samochodów Pancernych przy 10 Pułku Ułanów ${ }^{41}$.

O mjr Kioku wspominał Jerzy Kirchmayer: [...] Po kilku latach wyznaczono go na dowódce 14 dywizjonu artylerii konnej w Białymstoku, ale coś tam napaskudzit na tym stanowisku. Odebrano mu dowodzenie i zostat wyktadowca taktyki artylerii w Centrum Wyszkolenia Piechoty w Rembertowie. Zdaje mi się, że w okresie 1935-1939 wydobyt sie z impasu i znowu zostat użyty na stanowisku liniowym. [...] $]^{42}$. Widziatem raz mjra Kioka $w$ krytycznej sytuacji. Wtaśnie zostat dowódca 14 daku. Byto to na poligonie pohulanka. Przyjechat jakiś generat - artylerzysta, ale $w$ duchu kawalerzysta - a więc albo gen. Romer, albo gen. Rómmel. Zdaje mi się, że byt to Romer. Zrobiono przed nim defilade dywizjonów artylerii konnej. Na czele 14 daku jechat galopem (cała defilada była oczywiście $w$ galopie, artyleria lekka defilowała zwykle $w \mathrm{klu}$ sie, ciężka - w stepie) Kiok - bardzo słaby jeździec (siedziat - jak mówiq - „na jajach”). Przed samym generatem rumak Kioka zbuntowat się - snadź byt przyzwyczajony do lepszych jeźdźców - $i$ zapart się $w$ piasek czterema nogami. Nie dat się ruszyć z miejsca. Pędzacy z tyłu dywizjon omal nie rozjechat

\footnotetext{
38 Za przykład może posłużyć przebieg służby wspomnianego płk Aleksandra Hertla, który na stanowisku dowódcy dywizjonu artylerii konnej awansował do stopnia płk. ze starszeństwem 1 I 1932 r.

39 P. Zarzycki, 14 Dywizjon Artylerii Konnej, Pruszków 2001, s. 12.

40 Dz. Personalny MSWojsk., Nr 15 z 27 III 1926 r., s. 103.

41 A. Smoliński, Organizacja kawalerii samodzielnej Rzeczypospolitej Polskiej w latach 1921-1929 , „Klio” 2001, t. 1, s. 69.

42 J. Kirchmayer, op. cit., s. 199.
} 
swego dowódcy. Ocalito Kioka obszerne pole, na którym odbywała się defilada. Można więc byto minąc go w ostatniej chwili. Ale autorytet Kioka wobec podwtadnych $i$ opinia jego u generała zostały narażone na niepowetowany szwank. $Z$ takiego despektu oficer nie mógt już nigdy wygrzebać się $w$ naszej artylerii konnej ${ }^{43}$. $\mathrm{Z}$ wierzchowcami różnie bywało, a wypadek mjr Kioka nie był odosobniony w armii II Rzeczypospolitej. Opinię Kirchmayera niezupełnie potwierdzają dokumenty. Po dokonaniu inspekcji w dywizjonie gen. Rómmel wydał 13 lipca 1926 r. rozkaz, w którym m.in. czytamy: [...] majorowi Kiokowi, który w tak krótkim czasie potrafit kardynalnie przerobić powierzony sobie oddziat $i$ od razu podnióst wartość bojowa i artyleryjska 14 dak do tak wysokiego poziomu, wyrażam specjalne podziękowanie i powinszowanie $[\ldots]^{44}$. Nieco później, bo 26 października tego roku, dowódca artylerii konnej 1 Dywizji Kawalerii płk Witold Majewski ocenił go jako wybitnego oficera. Identyczną notę wystawił były dowódca dywizji, a wówczas generał do prac przy Generalnym Inspektorze Sił Zbrojnych gen. Rómmel ${ }^{45}$. Opinie te potwierdził dowódca OK nr III Grodna gen. dyw. Kazimierz Dzierżanowski ${ }^{46}$. Z końcem kwietnia 1927 r. odchodzący na dowódcę 22 Pułku Artylerii Polowej płk Majewski ${ }^{47}$ napisał opinię dodatkową:

I. Zalety osobiste: Charakter o silnej woli, bezwzględnie daży do wytkniętego sobie celu. W stosunku do przełożonych i podwtadnych nie zawsze szczery. Ambicja własna rozwinięta $w$ wysokim stopniu. Zarozumiały na punkcie oceny wtasnej wartości. W stosunku do przełożonych przesadnie dyscyplinowany. Obycie towarzyskie wyrobione. W postępowaniu jednak jak $w$ służbie tak $i$ poza niq nie zawsze taktowny.

II. Wartość fizyczna: bardzo ruchliwy i sprężysty. Posiada dar słowa, co pozwala mu $w$ dużej mierze do osiagnięcia zamierzonych celów.

III. Inteligencja: Bardzo sprytny $i$ zdolny. Umyst bystry, prędko orientuje sie $w$ wytworzonej sytuacji i opanowuje ją.

IV. Zdolności kierownicze: Pewny siebie i energiczny. Jako kierownik $i$ wychowawca korpusu oficerskiego wykazał mało praktyki zyciowej. Nie zdołał wzbudzić do siebie zaufania podwładnych.

V. Ogólna wartość służby: Posiada obszerne wiadomości jak fachowe, tak i ogólne wojskowe. Użyty może być jako instruktor $i$ wykładowca.

\footnotetext{
43 Ibidem, s. 199-200.

44 CAW, AP. Kioka L., 22551, 10851, Wyciąg z rozkazu ogólnego Dowództwa 1 Dywizji Kawalerii $\mathrm{nr} 7$ pkt 1 z 13 VII 1926 r.

45 Dz. Personalny MSWojsk., Nr 38 z 20 IX 1926 r., s. 306-307.

46 CAW, AP. Kioka L., 22551, 10851, Roczne uzupełnienie listy kwalifikacyjnej za rok 1926.

47 Dz. Personalny MSWojsk., Nr 12 z 11 IV 1927 r., s. 111; R. Loś, Artyleria polska 1914-1939, Warszawa 1991, s. 189.
} 
VI. Ocena ogólna: W rocznym uzupetnieniu za rok 1926 oceniłam mjr Kioka jako wybitnego, a to na zasadzie wyników jego pracy w 14 dak w czasie szkoły ognia i manewrów kawaleryjskich. W ciagu jednak okresu pracy zimowej okazało się że ocena byta przedwczesna. Oficer ten pierwszorzędny instruktor i wykładowca zupetnie nie jest przygotowany do prowadzenia korpusu oficerskiego. Obecnie oceniam mjr Kioka jako bardzo dobrego oficera artylerii, lecz jeszcze nie przygotowanego do prowadzenia samodzielnego oddziału ${ }^{48}$. Dowódca dywizji płk Grabowski 4 sierpnia dodał: Charakter niewyrobiony - zarozumiały - brak taktu - z powodu czego ciagłe nieporozumienia z korpusem oficerskim - zupetnie jeszcze niewyrobiony na samodzielne stanowisko - dywizjon artylerii konnej którym dowodzit przeszło rok byt pod każdym względem w złym stanie. Osobiście posiada wybitne wiadomości fachowe, ale nie umie ich zastosować $w$ praktyce b. inteligentny - sprytny $i$ zdolny - nadaje się na stanowisko dcy baterii - pod kontrola dobrego dcy putku może się wyrobić na dobrego oficera - czasowo na samodzielne stanowisko nie nadaje się ${ }^{49}$.

Wydaje się, że te niskie noty przyczyniły się do odebrania majorowi dowództwa. Rozporządzeniem ministra spraw wojskowych 17 maja 1927 r. został zwolniony z zajmowanego stanowiska i przeniesiony do Kadry Oficerów Artylerii. Jednocześnie oddano go do dyspozycji dowódcy OK nr III Grodno $^{50}$. Jego następcą 19 czerwca został ppłk Brunon Romiszewski ${ }^{51}$, który został przeniesiony $\mathrm{z}$ zastępcy dowódcy 2 Pułku Artylerii Polowej Legionów ${ }^{52}$. Przełożonym mjr. Kioka był wówczas dowódca grodzieńskiego korpusu gen. bryg. Gustaw Truskolaski ${ }^{53}$ zastąpiony latem przez gen. bryg. Aleksandra Litwinowicza ${ }^{54}$.

Zauważmy, że na stanowisku w Białymstoku Kiok nie otrzymał awansu na ppłk. ${ }^{55}$ Co więcej, spośród trzynastu dowódców dywizjonów artylerii konnej był wówczas jedynym majorem (tabela 1 ).

48 CAW, AP. Kioka L., 22551, 10851, Opinia dodatkowa za okres 1 I - 1 V 1927 r. Dowództwa Artylerii Konnej 1 Dywizji Kawalerii z 30 IV 1927 r.

49 CAW, AP. Kioka L., 22551, 10851, Opinia za IV kwartał 26 r. i I i II kwartał 27 r.

50 Dz. Personalny MSWojsk., Nr 15 z 23 V 1927 r., s. 144.

51 P. Zarzycki, 14 Dywizjon..., s. 12.

52 Dz. Personalny MSWojsk., Nr 44 z 14 X 1926 r., s. 356; Dz. Personalny MSWojsk., Nr 15 z 23 V 1927 r., s. 144, 147; J. Królikowski, Generatowie $i$ admiratowie Wojska Polskiego 1943-1990, t. II, Toruń 2010, s. 318. Autor podał, że dowództwo dyonu objął 14 VI.

53 Dz. Personalny MSWojsk., Nr 10 z 19 III 1927 r., s. 92-93.

54 Dz. Personalny MSWojsk., Nr 19 z 22 VII 1927 r., s. 214.

55 K. L. Galster, Księga pamiątkowa artylerii polskiej 1914-1939, Londyn 1975, s. 96. Tu mylnie został podany w stopniu ppłk. Otóż z pośród dowódców tego oddziału (mjr Stefan Dowbor, ppłk tyt. płk Witold Majewski, ppłk Adam Sielicki, ppłk Brunon Romiszewski, ppłk Włodzimierz Arwaniti, ppłk Jan Kijowski, ppłk dypl. Tadeusz Żyborski) tylko Dowbor i Kiok opuścili jego szeregi w stopniu mjr. 
Tabela 1. Dowódcy dywizjonów artylerii konnej na przełomie 1926/1927 r.

\begin{tabular}{|l|l|c|l|}
\hline DAK & \multicolumn{1}{|c|}{ Stopień, imię i nazwisko } & DAK & \multicolumn{1}{|c|}{ Stopień, imię i nazwisko } \\
\hline 1 & ppłk SG Antoni Durski-Trzasko & $8^{\text {B }}$ & mjr Ludwik Kiok \\
2A & ppłk Edward Robakiewicz & 9 A & ppłk Jan Dunin-Wąsowicz \\
3A & ppłk Stefan Trzebiński & 10 & ppłk August Trzos \\
4 & ppłk Witold Poray-Kuczewski & 11 & ppłk dr Włodzimierz Leon Dembiński \\
5A & ppłk Alojzy Szuster & 12 & ppłk Jan Zagrojski \\
6A & ppłk Stefan Maleszewski & 13 & ppłk Aleksander Hertel \\
7 & ppłk Zygmunt Lakiński & & \\
\hline
\end{tabular}

\section{Uwaga:}

A Dywizjony artylerii konnej mające w swoim składzie po trzy baterie.

B K. L. Galster, Ksiega pamiątkowa artylerii polskiej 1914-1939, Londyn 1975, s. 95. Tu podano, że przemianowanie na 14 Dywizjon Artylerii Konnej miało miejsce w 1927 r.

Źródło: Dz. Personalny MSWojsk., Nr 15 z 23 V 1927 r., s. 147, 151; P. Zarzycki, 1 Dywizjon Artylerii Konnej im. gen. Józefa Bema, Pruszków 1999, s. 17; idem, 2 Dywizjon Artylerii Konnej im. gen. Józefa Sowińskiego, Pruszków 2000, s. 17; idem, 3 Lubelski Dywizjon Artylerii Konnej im. pułkownika Włodzimierza Potockiego, Pruszków 2001, s. 20; idem, 4 Dywizjon Artylerii Konnej, Pruszków 2000, s. 16; idem, 5 Dywizjon Artylerii Konnej, Pruszków 2001, s. 21; idem, 6 Dywizjon Artylerii Konnej im. gen. Romana Sottyka, Pruszków 1996, s. 24; idem, 13 Dywizjon Artylerii Konnej, Pruszków 1996, s. 20; A. Kostrzewski, 9 Dywizjon Artylerii Konnej, Pruszków 1996, s. 11.

Trudno dociec, czym wówczas zajmował się mjr Kiok. Wiadomo natomiast, że rozporządzeniem ministra spraw wojskowych, z końcem listopada 1927 r. został przydzielony (z dyspozycji dowódcy OK nr III) do Obozu Szkolnego Kawalerii na stanowisko wykładowcy nauki o broni i artylerii ${ }^{56}$. Antoni Kamiński wspominał: „Taktykę kawalerii wykładał nam dowódca plutonu, por. Szeliski ${ }^{57}$, artylerii - major Kiok [...]"58.

W Grudziądzu przełożonym mjr Kioka był płk Zygmunt Podhorski ${ }^{59}$ komendant obozu, przekształconego w maju 1928 r. w Centrum Wyszkolenia Kawalerii $^{60}$. W lipcu 1935 r. został mianowany dowódcą 13 Brygady Kawalerii, a w Grudziądzu zastąpił go dotychczasowy dowódca 2 Pułku Ułanów Grochowskich imienia generała Dwernickiego płk dypl. Józef Marian Smoleń-

\footnotetext{
56 Dz. Personalny MSWojsk., Nr 27 z 29 XI 1927 r., s. 349.

57 Prawdopodobnie chodzi tu o por. Stanisława Włodzimierza Szeliskiego, służącego później w 16 Pułku Ułanów Wielkopolskich.

58 B. Królikowski, Ułańska jesień. Szkice z dziejów kawalerii II Rzeczypospolitej, Lublin 2002, s. 130.

59 Dz. Personalny MSWojsk., Nr 15 z 23 V 1927 r., s. 144.

60 Dz. Rozkazów MSWojsk., Nr 13 z 18 V 1928 r., s. 112.
} 
ski $^{61}$. Funkcję dyrektora nauk sprawował wtenczas ppłk SG Konstanty Drucki-Lubecki, który w listopadzie 1928 r. został przeniesiony na stanowisko zastępcy dowódcy 13 Pułku Ułanów Wileńskich ${ }^{62}$. Zastąpił go ppłk dypl. Leon Strzelecki63, którego we wrześniu 1930 r. przeniesiono na stanowisko dowódcy 1 Pułku Ułanów imienia Pułkownika Bolesława Mościckiego ${ }^{64}$. Jego następcą natomiast został ppłk dypl. Witold Gierulewicz ${ }^{65}$, przeniesiony w marcu 1931 r. na stanowisko zastępcy dowódcy 2 Pułku Ułanów ${ }^{66}$. Kolejnym dyrektorem nauk był mjr dypl. Stanisław Chmielowski ${ }^{67}$. Zastąpił go oficer sztabu mjr dypl., a od stycznia 1933 r. - ppłk dypl. Władysław Płonka (starszeństwo 1 I 1933) ${ }^{68}$.

Sadząc po opiniach wystawionych przez przełożonych, mjr Kiok na tym stanowisku spisywał się wyśmienicie. Płk SG Drucki-Lubecki z datą 22 października 1928 r. ocenił go jako wybitnego oficera. Opinię podobnej treści napisał 25 października komendant centrum: [...] Jako wykładowca wybitny, ogólnie b. dobry ${ }^{69}$. Jako wybitnego oficera ocenił go 11 października 1929 r. ppłk dypl. Strzelecki. Natomiast dwa dni wcześniej płk Podhorski napisał: Oficer o wielkiej inteligencji i bystrym umyśle. Surowy, bardzo sumienny i pracowity. Wielkich zdolności jako wyktadowca - charakter twardy wyrobiony. Wybitny oficer $i$ wykładowca. Oficer na wskroś liniowy. Nadaje się na samodzielne stano$w_{i s k o^{70}}$. Identyczne noty otrzymał od nich w lipcu 1930 r. ${ }^{71}$ Pod koniec sierpnia 1931 r. opiniowali go ppłk dypl. Gierulewicz i płk Podhorski, zgodnie uznając za wybitnego ${ }^{72}$. Notę tę komendant podtrzymał także w roku następnym, zaś mjr dypl. Chmielowski ocenił go jako bardzo dobrego, zaś w opinii facho-

61 Dz. Personalny MSWojsk., Nr 10 z 4 VII 1935 r., s. 90; A. Dobroński, 2 Pułk Ułanów Grochowskich im. gen. Józefa Dwernickiego, Pruszków 1993, s. 13; Ósmy ułan Beliny. Generał brygady Józef marian Smoleński „Kolec” (1894-1978), mat. zebrał i oprac. M. Smoleński, red. nauk. G. Nowik, Warszawa 2008, s. 233, 234, 267 i n.

62 Dz. Personalny MSWojsk., Nr 14 z 5 XI 1928 r., s. 341; T. Kryska-Karski, S. Żurakowski, Generałowie Polski Niepodległej, Warszawa 1991, s. 89; P. Stawecki, Oficerowie dyplomowani wojska Drugiej Rzeczypospolitej, Wrocław, Warszawa, Kraków 1997, s. 35, 78, 148.

63 Dz. Personalny MSWojsk., Nr 14 z 5 XI 1928 r., s. 364.

64 Dz. Personalny MSWojsk., Nr 14 z 20 IX 1930 r., s. 297; K. Krzeczunowicz, Rodowody pułków jazdy polskiej 1914-1947, Londyn 1983, s. 57.

65 Lista oficerów dyplomowanych, Warszawa 1931, s. 18; P. Stawecki, Oficerowie dyplomowani..., s. $44,78$.

66 Dz. Personalny MSWojsk., Nr 6 z 23 III 1932 r., s. 236.

67 Dz. Personalny MSWojsk., Nr 13 z 9 XII 1932 r., s. 408.

68 Dz. Personalny MSWojsk., Nr 13 z 9 XII 1932 r., s. 420.

69 CAW, AP. Kioka L., 22551, 10851, Roczne uzupełnienie listy kwalifikacyjnej za rok 1928.

70 CAW, AP. Kioka L., 22551, 10851, Roczne uzupełnienie listy kwalifikacyjnej za rok 1929.

71 CAW, AP. Kioka L., 22551, 10851, Roczne uzupełnienie listy kwalifikacyjnej za rok 1930.

72 CAW, AP. Kioka L., 22551, 10851, Roczne uzupełnienie listy kwalifikacyjnej za rok 1931. 
wej dodał: Wybitny wykładowca artylerii. Natomiast płk Podhorski zanotował: Wybitny wykładowca artylerii, oficer o wybitnie wyrobionym [...] charakterze, umyst taktycznie bardzo wyrobiony. Ponadto dodał: Uważam majora Kioka za jednostkę wybitnq tak pod względem umystu który wyróżnia się wybitnq wiedza, jak też inteligencją. Umyst bezwzględnie twórczy. W każdej dziedzinie która mu jest polecona wykazuje twórczość. Wybitny fachowiec ${ }^{73}$.

Dodam w tym miejscu, że sprawa honorowa, o której wspomniał płk Podhorski, zakończyła się 20 kwietnia 1932 r. Otóż ,,[...] za naruszenie godności oficerskiej przez to, że postępowaniem swem w stosunku do żony oficera kolegi stworzył warunki narażające go na ciężką zniewagę [...]", Sąd Honorowy dla Oficerów Sztabowych przy DOK nr VIII Toruń ukarał go naganą ${ }^{74}$.

Fakt ten nie wpłynął na zmianę not z opinii w kolejnych latach. W $1933 \mathrm{r}$. został oceniony przez ppłk dypl. Płonkę i płk Podhorskiego jako wybitny oficer sztabowy ${ }^{75}$. Oficer sztabu centrum ppłk dypl. Płonka w opinii z 10 listopada 1935 r. zaproponował go na stanowisko zastępcy dowódcy pułku artylerii. Ponadto pułkownik ten stwierdził, że po odbyciu praktyki w linii, Kiok może dowodzić dywizjonem artylerii konnej. Opiniowany mógł też służyć w szkolnictwie jako wykładowca artylerii na kursach oficerskich. Natomiast nowy komendant płk dypl. Smoleński, opierając się na opiniach swojego poprzednika i oficera sztabu dodał: „Mało mi jeszcze znany [...]”"76.

Wysokie noty otrzymywane przez szereg lat przełożyły się na awans. Zauważmy, że w 1935 r., w korpusie oficerów artylerii Kiok był jedynym służącym majorem ze starszeństwem 1 czerwca $1919 \mathrm{r} \cdot{ }^{77}$ Do stopnia ppłk awansował ze starszeństwem z 1 stycznia 1936 r. W korpusie oficerów artylerii zajął pierwszą lokatę, wyprzedzając szesnastu oficerów ${ }^{78}$.

W ślad za awansem nastąpiła zmiana stanowiska, ponownie na liniowe. Od 12 lutego 1936 r. pełnił funkcję zastępcy dowódcy 16 Pułku Artylerii Lekkiej. Jego bezpośrednim przełożonym był dowódca tego pułku, cieszący dobrymi opiniami przełożonych, płk Witold Andruszewicz ${ }^{79}$. Pułk ten wchodził w skład 16 Dywizji Piechoty gen. bryg. Kazimierza Sawickiego, którego w lutym 1938 r. zastąpił płk dypl. Stanisław Jan Świtalski. Natomiast pod względem wyszkole-

73 CAW, AP. Kioka L., 22551, 10851, Roczne uzupełnienie listy kwalifikacyjnej za rok 1932.

74 CAW, AP. Kioka L., 22551, 10851, Roczne uzupełnienie listy kwalifikacyjnej za rok 1932. Tu podano pismo Sądu Honorowego dla oficerów sztabowych DOK VIII w Toruniu L. dz. 35/32 pfn. z 20 IV 1932 r.; ibidem, Pismo DOK VIII Sztab Oddz. Ogólny L. dz. 2243/Pers. z 7 VIII $1931 \mathrm{r}$.

75 CAW, AP. Kioka L., 22551, 10851, Roczne uzupełnienie listy kwalifikacyjnej za rok 1933.

76 CAW, AP. Kioka L., 22551, 10851, Roczne uzupełnienie listy kwalifikacyjnej za rok 1935.

77 Instytut Józefa Piłsudskiego w Ameryce, Archiwum Józefa Piłsudskiego, 701.1.116, s. 119.

78 R. Rybka, K. Stepan, Awanse oficerskie w Wojsku Polskim 1935-1939, Kraków 2003, s. 339.

79 J. Krzyś, 16 Pułk Artylerii Lekkiej, Pruszków 1998, s. 17. 
nia podlegał dowódcy 8 Grupy Artylerii płk Józefowi Koryckiemu ${ }^{80}$. Od maja 1937 r. pułki tej wielkiej jednostki piechoty kontrolował generał do prac przy Generalnym Inspektorze Sił Zbrojnych gen. bryg. Władysław Bortnowski ${ }^{81}$.

Na tym stanowisku ppłk Kiok odpowiadał przede wszystkim za wyszkolenie pułku. $\mathrm{Z}$ ocen wystawionych przez przełożonych wynika, że z zadania tego wywiązywał się co najmniej dobrze. Płk Andruszewicz 30 października $1936 \mathrm{r}$. napisał m.in.: Na zajmowanym stanowisku zupetnie dobry. Po dokładnym zapoznaniu się $z$ praktycznym życiem liniowym $i$ wspótpraca $z$ piechota będzie pełnowartościowym dowódca pułku w czasie wojny ${ }^{82}$. Gen. Sawicki opiniował go 4 listopada: Zgadzam się z trafnq dcy putku. B. Zdolny, inteligentny oficer. Dużo umie. Na razie jeszcze przewaga teorii nad praktyka. Dowódca z śmiata decyzja $i$ energia. $B$. pracowity $i$ ambitny. Zarozumiały. Na obecnym stanowisku b. dobry ${ }^{83}$. Generalnie na tym stanowisku oceniono go jako przeciętnego oficera $^{84}$. Wystarczyło to, aby ponownie powierzyć mu samodzielne stanowisko.

Od 8 lipca 1938 r. ppłk Kiok dowodził stacjonującym w Suwałkach 4 Dywizjonem Artylerii Konnej ${ }^{85}$. Był ostatnim dowódcą tego oddziału ${ }^{86}$, którego charakteryzowały żurawiejki: „Z dumy rośnie moje serce, Bo przoduje w woltyżerce”, oraz „Czy to w knajpie, czy w bardaku, Zawsze ktoś z czwartego dak'u”"

Dywizjon ten wchodził w skład Suwalskiej Brygady Kawalerii ${ }^{88}$ dowodzonej przez płk, a od marca 1939 r. gen. bryg. Zygmunta Podhorskiego. Natomiast pod względem wyszkolenia podlegał dowódcy 3 Grupy Artylerii płk Rudolfowi Niemirze (do IX 1938) ${ }^{89}$, a następnie płk dypl. Stanisławowi Künstlerowi ${ }^{90}$. Ponadto od wiosny 1937 r. zarówno Suwalska Brygada Kawalerii, jak i 3 Grupa

80 W. Jaskulski, Pułkownik Józef Korycki. Tatarski artylerzysta II Rzeczypospolitej. (Zarys biografii), Wrocław 2012, s. 79 i n.

81 CAW, Generalny Inspektorat Sił Zbrojnych (dalej GISZ), I. 302.4.391, Pismo GISZ L. 163/Spec. tjn. z 28 V 1937 r.

82 CAW, AP. Kioka L., 22551, 10851, Roczne uzupełnienie listy kwalifikacyjnej za rok 1936.

83 CAW, AP. Kioka L., 22551, 10851, Roczne uzupełnienie listy kwalifikacyjnej za rok 1936.

${ }^{84}$ CAW, MSWojsk. Biuro Personalne, I. 300.18.328, Wykaz dowódców i zastępców pułków artylerii.

85 P. Zarzycki, 4 Dywizjon Artylerii Konnej, Pruszków 2000, s. 16.

86 P. Zarzycki, Artyleria konna w 1939 roku, Warszawa 2007.

87 S. Radomyski, Żurawiejki, Pruszków 1995, s. 73; vide też P. Jaźwiński, Oficerowie i dżentelmeni. Życie prywatne i służbowe kawalerzystów Drugiej Rzeczypospolitej, Warszawa 2011, s. 174.

88 A. Smoliński, Organizacja kawalerii samodzielnej Wojska Polskiego w latach 1930-1939, „Klio” 2004, nr 5, s. 126.

89 E. Rujna, M. Szczurowski, Wyżsi dowódcy artylerii Wojska Polskiego w II wojnie światowej, Toruń 1995, s. 32.

90 I. Błagowieszczański, Artyleria Wojska Polskiego w latach 1918-1939, cz. I, „Wojskowy Przegląd Historyczny” (dalej „WPH”) 1974, nr 1, s. 267; idem, Artyleria Wojska Polskiego w latach 1918-1939, „WPH” 1974, nr 4, s. 210. 
Artylerii znalazły się w inspekcji wileńskiego inspektora armii gen. dyw. Stefana Dęba-Biernackiego ${ }^{91}$.

$\mathrm{Na}$ czele tego dywizjonu podpułkownik wyszedł we wrześniu wraz z brygadą na front ${ }^{92}$. Tę wielką jednostkę kawalerii podporządkowano dowódcy Samodzielnej Grupy Operacyjnej „Narew” gen. bryg. Czesławowi Młotowi-Fijałkowskiemu ${ }^{93} .20$ września gen. Podhorski zreorganizował podległe oddziały w Dywizję Kawalerii „Zaza”. W jej składzie znalazła się Brygada Kawalerii „Edward” płk Edwarda Milewskiego, któremu podporządkowano dywizjon ppłk Kioka ${ }^{94}$. Pod koniec września dywizja weszła do Ordre de Bataille Samodzielnej Grupy Operacyjnej „Polesie” gen. bryg. Franciszka Kleeberga ${ }^{95}$. W celu uderzenia na Wolę Gułowską brygadę płk Milewskiego podporządkowano dowódcy 60 DP płk Adamowi Eplerowi. W nocy z 4 na 5 października oddział ppłk Kioka otrzymał ostatnie uzupełnienie amunicji. 6 października gen. Kleeberg skapitulował ${ }^{96}$. $\mathrm{Na}$ wniosek gen. Podhorskiego za działania w kampanii polskiej 3 Bateria 4 Dywizjonu Artylerii Konnej została odznaczona Srebrnym Krzyżem Orderu Wojennego Virtuti Militari nr 1330497.

Ppłk Kiok dostał się do niewoli niemieckiej. Został osadzony w Oflagu VII A Murnau w Bawarii (nr jeniecki 16022) ${ }^{98}$. Przebywający od połowy 1942 r. w tym obozie gen. Rómmel ${ }^{99}$ w swoich opiniach napisał o nim m.in.: „Nadaje się na dowódcę pułku" ${ }^{100}$. Na obecnym etapie badań jego dalszych losów nie ustalono.

91 CAW, GISZ, I. 302.4.390, Pismo GISZ L. 163/Spec. tjn. z 28 V 1937 r.; CAW, GISZ, I. 302.4.391, Pismo GISZ L. 163/Spec. tjn. z 28 V 1937 r.

92 Vide też R. Rybka, K. Stepan, Najlepsza broń. Plan mobilizacyjny „W” $i$ jego ewolucja, Warszawa 2010, s. 347-348.

93 Polskie Sity Zbrojne w drugiej wojnie światowej, t. I, cz. I, Kampania wrześniowa. Polityczne $i$ wojskowe potożenie Polski przed wojna, Londyn 1951, szkice nr 9, 17, 25, tabela II; P. Zarzycki, Artyleria konna..., s. 105 i n.; A. Kuprianis, Generał brygady Czesław Młot-Fijałkowski (1892-1944), Warszawa 2004, s. 177 i n.

94 P. Dymek, Samodzielna Grupa Operacyjna Narew 1939 w polskiej historiografii wojskowej, Poznań 1999, s. 127 i n.

95 J. Wróblewski, Samodzielna Grupa Operacyjna „Polesie”, Warszawa 1989, s. 97 i n.

96 Vide też S. Giziński, A. Szutowicz, Oflag II B Arnswalde. Jenieckie losy, Wrocław 2013, s. $84,142$.

97 P. Zarzycki, 4 Dywizjon..., s. 28-29.

98 Centralne Muzeum Jeńców Wojennych w Łambinowicach - Opolu, Wast - Oflag VIIA, 1.6, Oberstleutnant Ludwik Kiok; vide też A. Pragłowski, Od Wiednia do Londynu. Wspomnienia, Londyn 1968, s. 218-223; A. Bukowski, Za drutami oflagów. Dziennik oficera 1939-1945, Warszawa 1993 , s. 322 i n.

99 F. Bornstaedt, W. Karbowski, Konspiracyjna organizacja wojskowa w Oflagu VII A Murnau, „WPH” 1979, nr 4, s. 85 i n.; vide też W. Karbowski, Ruch oporu w Oflagu VII A Murnau, „WPH” 1984, nr 4, s. 167 i n.; J. Stępień, Wspomnienia z Murnau, „Tarnobrzeskie Zeszyty Historyczne” 2008, nr 30, s. 105 i n.

100 Generała Juliusza Rómmla opinie o wyższych oficerach WP, „WPH” 1993, nr 1, s. 236. 


\section{Lieutenant colonel Ludwik Kiok. An artilleryman of the Second Polish Republic army}

Lieutenant colonel Ludwik Kiok was one of many Polish Army officers originally serving in the tsarist army. During WW I he served in the tsarist army and, after its disintegration, in the Polish I Corps in Russia and then in the Polish Military Organization.

After the war, he joined the Polish Army. He started his military service in Warsaw in the rank of lieutenant. During the Polish-Soviet war he was a troop commander of the I Regiment of Field Artillery of the Polish Legions, for which he was awarded with the highest combat badges. After the war he had under his command a heavy artillery squadron in Grodno. Despite positive opinions he received, in 1923 he was transferred to work in military education - as a lecturer.

In the spring of 1926 he temporarily commanded the 8 Squadron of Horse Artillery. Then, in the autumn of the following year, he was transferred to military education. This time to Centrum Wyszkolenia Kawalerii in Grudziądz, where in January 1936 he got promoted to the rank of lieutenant colonel.

In February of that year he was transferred to the 16 Regiment of Light Artillery, as deputy commander. In the spring of 1938 he was in charge of the 4 Squadron of Horse Artillery. He commanded it during the Polish campaign of 1939. During the battle of Kock he got into German bondage. He was sent to Oflag VII A Murnau in Bavaria.

In the time of war and peace, alike, he proved to be an excellent organizer, lecturer and commander. He was highly appreciated in all his functions. As a model soldier, he gained appreciation both from his superiors and subordinates.

Key words: Ludwik Kiok, biography, Polish officers of 1918-1939 